\title{
Debt and Economic Growth in Developing Countries: Jordan as a Case Study
}

\author{
Mahmoud Falah Al-Refai ${ }^{1}$ \\ ${ }^{1}$ Faculty of Administrative and Financial Sciences, University of Petra, Amman, Jordan \\ Correspondence: Mahmoud Falah AL-Refai, Faculty of Administrative and Financial Sciences, University of \\ Petra, P. O. Box: 961343, Amman, 11196, Jordan. Tel: 962-6-579-9555 ext. 9207. E-mail: mrefai@uop.edu.jo
}

Received: December 16, 2014

Accepted: December 29, 2014

Online Published: February 25, 2015

doi:10.5539/ijef.v7n3p134

URL: http://dx.doi.org/10.5539/ijef.v7n3p134

\begin{abstract}
The study examines empirically the relationship between debt and economic growth in Jordan during the period (1990-2013) using Cobb-Douglas production function. The estimated results of the study reveal that the gross fixed capital formation and domestic debt have positive and significant relationship with economic growth in Jordan, but labor, external debt, and long-term external debt have a negative and insignificant impact on economic growth in Jordan.
\end{abstract}

Keywords: external debt, domestic debt, economic growth, Jordan

\section{Introduction}

Most developing countries focus in their development plans on searching for funding sources necessary for the advancement of the different productive sectors of the economy. Borrowing is one of the sources used by developing countries to finance their economic development which resulted in high debt levels in these countries. According to the World Economic Outlook Report published by the International Monetary Fund (IMF) in 2000, the size of the debt of the developing countries has increasing from 62 billion dollars to 481 billion dollars during the period 1970-1980 and it then increased from 1,539 billion dollars to more than 2,038.8 billion dollars for the period 1990-1996.

The acute shortage of national savings in developing countries made them increase their borrowing to finance their economic development. According to World Bank statistics, the debtor countries have paid more than 4500 billion dollars during the period 1980-2001, but the indebtedness of these countries grew four times where the debt rose from 600 billion dollars in 1980 to 2,500 billion dollars in 2001 .

The external debt crisis erupted when Mexico announced in 1982 its inability to fulfill its debt of 92 billion dollars and followed by other countries such as Argentina and Brazil; Mexico asked its creditors to reschedule its debt and reduce its indebtedness and exempt it from any debt service. In addition to Mexico, other countries announced their inability to repay their external debt, such as Sudan, Egypt, Argentina, and Turkey. According to the Unified Arab Economic Report issued by the Arab Monetary Fund, the total debt service has increased for the indebted developing countries to nearly 22 billion dollars in 1974 and to 76.2 billion dollars in 1990, and then jumped to 331.8 billion dollars in 1999.

Jordan, like other developing countries, suffers from several economic problems resulting from the lack of financial resources such as low productive capacity of the national industries, low volume of Jordanian exports, and the transfer of a large section of public and private spending toward imports of consumer and capital goods, which led to a chronic and persistent deficit in the trade balance, and an increase on relying on external funding sources of aid, grants, and loans.

With regard to the impact of debt on the economies of developing countries, some argue that the debt used in financing the production and export development and import substitution has led to increased national income and national savings which has a positive impact on the balance of payments. Others argue that debt is not directed to the productive sectors in the economy, but it is loading future generations with the consequences of these debt and their payments.

Literature review on the impact of foreign loans on economic growth shows that there are two groups: The first group follows the traditional school who believe that external borrowing has a positive impact on the economies 
of developing countries. This school argues that the cause of low levels of development in developing countries is the decrease in national savings and the balance of foreign currency which cause developing countries to suffer two gaps: Saving Gap and Foreign Currency Gap. Saving gap represents the difference between domestic savings and domestic investment, while foreign currency gap represents the difference between a country's exports and imports. The positive impact of loans and foreign aid on the saving gap can be direct through its contribution to the increase in investment, and indirect through an increase in the domestic capital accumulation which will enable the country to reduce the size of that gap by increasing the level income, which will in turn increase the rate of domestic savings (Chenery \& Carter, 1973). As for the gap of foreign currency, the loans and foreign aid become a new source of foreign currency, which will help the receiving countries to have access to the import requirements of capital and intermediate goods that can be used to increase the production of various economic sectors, which will ultimately increase the volume of exports and thus reduce the size of that gap and also contributes to achieving an increase in the rate of economic growth (Momani, 1995).

The second group contradict the views of the traditional school and argues that the impact of debt is very weak on national income and economic growth because of two reasons: First, debt lowers rates of domestic saving, since a large part of the loans and foreign aid is used to increase the level of consumption and not to increase the volume of domestic savings, due to the change in the composition of government expenditures in favor of consumption which results in a decline in the marginal propensity to save (MPS) and an increase in the marginal propensity to consume (MPC). In addition, large portion of the loans and foreign aid were allocated for infrastructure and capital-intensive projects, due to factors such as donor organizations' loans requirements, or predetermined loans usage which limits the borrowing countries ability to choose production methods available and that are consistent with the investment needs of that state.

This study attempts to measure the impact of debt on economic growth in Jordan by examining whether the debt help promote economic growth, or that the debt become a burden on the economy.

The rest of the paper is organized as follows. Section 2 provides an overview of the External Debt in Jordan. Section 3 provides a review of the literature, and section 4 describes the data and the empirical methodology used in the study. Section 5 discusses the empirical results while section 6 concludes the study.

\section{The External Debt: A Background of the Public Debt of Jordan}

Since its independence, Jordan has faced many economic problems of which the deficit in the balance of payments was a major problem which prompted Jordan to rely more on external loans to finance this deficit in its balance of payments. The statistics indicate that Jordan resorted to external borrowing during the financial year 1949-1950, where it signed its first external loan from the British government for one million Jordanian dinars. Official statistics show that the size of external public debt of Jordan as a percentage of GDP was 30.3 percent in 2013 of which 41.5 percent was denominated in the US dollar.

Both local and international reports show that the increase in the volume of public debt and its debt service, especially the external loans, exert a high burden on the national economy and affect public expenditures where 13 percent of local revenues were cut from financing investment projects. In addition, the increase in the cost of foreign loans has increased the burden on Jordan economy by decreasing its foreign reserves.

Several factors have contributed to an increase in the Jordanian public debt such as general budget deficit and the government insurance of loans to some other government institutions.

To reduce the size of the debt over the past years, the government of Jordan has implemented economic and social reform and also used different measures such as exchanging some of its foreign debt, buying some other debt, and rescheduling others. These measures have initially reduced the ratio of debt to GDP. However, the substantial increase in the budget deficit since the beginning of the global financial crisis coupled with the effects associated with the Arab Spring, and the government guarantee for the loans taken by the National Electric Company due to the interruption in the Egyptian natural gas supply, the public debt (internal and external) has increased substantially and exceeded the accepted target. Published data indicates that at the end of 2013, the size of the debt, internal and external has reached 20.7 billion Jordanian Dinar which is equivalent to 29 billion U.S. dollar. (The exchange rate is one Jordanian Dinar equals 1.41 USA dollars). This accounts for about 86.6 percent of GDP. The increase in public debt to this level is an indicator of critical situation due to its negative implications on the economy which include public debt service, decrease in economic growth, and the increase in the interest rates as a result of the increase in the government demand for borrowing from local banks. According to data published by the Central Bank of Jordan, the interest rate on three-year treasury bonds reached 8.6 percent. 
To finance its budget deficit and to increase domestic liquidity, the government resorted to borrowing from international financial institutions which have a short run effects such as increasing the foreign currency reserves and supporting the government to secure funding for government ministries and units without competing with the domestic private sector. In addition, the government has used a program of economic and financial reform and adopted plans and strategies to minimize the burden of these foreign loans, and be able to pay them back on time and without having negative impact on economic and financial indicators.

To control public debt, the government has enacted legislations such as the Public Debt Law in 2001, of which articles (21) and (22) stipulate that the ratio of net public debt (both domestic and external) to GDP not to exceed 40 percent at the current prices for the last year for which data are available. In addition, article (23) of the same law requires that the gross public debt not to exceed 60 percent of GDP at any time, and article (24) states that both articles (22) and (23) become effective from the date decided by the Council of Ministers. However, not including a statement in the law to make the Council of Ministers specify the date (after it has been determined in previous years and then re-examined in the light of developments in that time) makes it a non-binding for governments to restrict the debt and lead to a continuation of the fear of its percentage to rise without the presence of tight control.

The development of the external debt of Jordan can be classified over time into three periods. These are:

First Period: 1990-1996.

During this period, the ratio of external debt to GDP has exceeded 100 percent. Table 1 shows that the external public debt fluctuates over time. It has reached 4,300 million Jordanian Dinar in 1990 and increased to 5,164.3 million Jordanian Dinar in 1996. The appreciation in the Japanese Yen has led to the increase in the value of the loans denominated in the Japanese Yen.

Second Period: 1997-2005.

Over this period, the ratio of external debt to GDP has reached a value of 50 percent to 100 percent. The balance of the external public debt during this period increased from 4,998.1 million Jordanian Dinar in 1997 to 5,056.7 million Jordanian Dinar in 2005.

Table 1. External debt and domestic debt as percentage of GDP

\begin{tabular}{|c|c|c|c|c|}
\hline Year & $\begin{array}{c}\text { External Debt } \\
\text { Million Jordanian Dinar }\end{array}$ & $\begin{array}{c}\text { Domestic Debt } \\
\text { Million Jordanian Dinar }\end{array}$ & $\begin{array}{c}\text { (External Debt/GDP) } \\
(\%) \\
\end{array}$ & $\begin{array}{c}\text { (Domestic Debt/GDP) } \\
(\%)\end{array}$ \\
\hline 1990 & 4300.0 & 1119.5 & 155.7 & 40.5 \\
\hline 1991 & 4400.0 & 1119.1 & 148.7 & 37.8 \\
\hline 1992 & 4577.6 & 1119.8 & 126.8 & 31.0 \\
\hline 1993 & 4229.6 & 1118.3 & 108.9 & 28.8 \\
\hline 1994 & 4720.5 & 1121.4 & 108.3 & 25.7 \\
\hline 1995 & 4911.8 & 1115.3 & 104.2 & 23.7 \\
\hline 1996 & 5164.3 & 1127.5 & 105.1 & 23.0 \\
\hline 1997 & 4998.1 & 1103.0 & 97.3 & 21.5 \\
\hline 1998 & 5333.7 & 1152.0 & 95.1 & 20.5 \\
\hline 1999 & 5510.1 & 1054.0 & 95.4 & 18.2 \\
\hline 2000 & 5043.5 & 1235.0 & 84.1 & 20.6 \\
\hline 2001 & 4969.8 & 1397.0 & 78.1 & 22.0 \\
\hline 2002 & 5350.4 & 1656.0 & 78.8 & 24.4 \\
\hline 2003 & 5391.8 & 1815.0 & 74.6 & 25.1 \\
\hline 2004 & 5348.8 & 2082.0 & 66.1 & 25.7 \\
\hline 2005 & 5056.7 & 2467.0 & 56.7 & 27.6 \\
\hline 2006 & 5186.5 & 2961.0 & 46.8 & 26.7 \\
\hline 2007 & 5253.3 & 3695.0 & 41.7 & 29.3 \\
\hline 2008 & 3640.2 & 5754.0 & 22.6 & 35.7 \\
\hline 2009 & 3869.0 & 7086.0 & 22.9 & 41.9 \\
\hline 2010 & 4610.8 & 7980.0 & 24.6 & 42.5 \\
\hline 2011 & 4486.8 & 9996.0 & 21.9 & 48.8 \\
\hline 2012 & 4932.4 & 12678.0 & 22.5 & 57.7 \\
\hline 2013 & 7234.5 & 13440.0 & 30.3 & 56.3 \\
\hline
\end{tabular}


Third Period: 2006-2013.

As Table 1 shows, the ratio of external debt to GDP was less than 50 percent during this period. As Table 1 shows, the external debt was 5,186.5 million Jordanian Dinar in 2006 and increased to 5,253.3 Jordanian Dinar in 2007 due to high exchange rate of the main currencies of creditor nations against the U.S. dollar and thus against the Jordanian Dinar. The external debt then decrease in 2008 to 3,640.2 million Jordanian Dinar as a result of the implementation of the repurchase agreements of non-concessional loans with member states of the Paris Club.

It is worth mentioning that during the period 2009-2013, the government reliance on domestic debt was more than external debt. Therefore, the Jordanian government raise the ratio of domestic debt to GDP specified in the public debt law to about 40 percent.

\section{Literature Review}

Literature review shows that many studies have discussed the impact of debt on economic variables, and the results of these studies have been mixed; some show a positive relationship, and others found that there is an inverse relationship.

Lyoha and Milton (1999) used simulations approach to study the impact of external debt on economic growth in sub-Saharan Africa for the period 1970 to 1994 and found that the external debt lowers the investment thus adversely affect economic growth.

Another study by Karagol (2002) used the common multi-technology integration to test the causality relation between servicing external public debt and economic growth in Turkey for the period 1956 to 1996, and found an inverse relationship between the external public debt and economic growth in the long term.

However, Schclarek (2004) found no evidence that the external public debt affects the productivity of the factors of production; instead the study found in developing countries that the rate of high economic growth is linked to lower rates of external public debt and not external private debt ratios. Adepoju et al. (2007) found that the accumulation of foreign debt hinders economic growth in Nigeria. In addition, Mallik et al. (2010) found that the external debt and debt service have a negative impact on economic growth in Pakistan during the period 1972 to 2002. Hameed et al. (2008) also found negative relationship between the external debt, equity capital, and manpower and the economic growth in Pakistan for the period 1976-2003.

Jayaraman and Evan (2008) study confirmed that the high flow of aid and foreign debt has contributed significantly to high rates of economic growth in the six countries of the Pacific during the period 1988 to 2004 .

A study by Butts (2009) shows the existence of a causal relationship between economic growth and the external public debt in 13 out of 27 countries of Latin America and the Caribbean during the period 1970-2003.

A study by Momani (1995) of the effects of external debt on the Jordanian economy found that the lack of domestic savings, the chronic deficit in the balance of trade, and the deficit in the government budget, are the most significant reasons of the Jordan external debt, which led to the high volume of external debt over the past years making Jordan unable to pay its debts without being rescheduled. In addition, the study found that foreign loans have positive effect on GDP, consumption, investment, exports, and imports, while a negative impact on domestic savings, but it lacks the statistical significance. However, loans did not help achieve high growth rates in Jordan.

On another study of the external debt on the Jordanian economy, Abdulhadi (2013) concluded that there is a negative impact of external debt on each of the economic growth, consumption, domestic savings, investment, and the balance of trade, both exports and imports.

\section{Data and Methodology}

The study attempts to measure the impact of debt on economic growth in the case of Jordan during the period (1990-2013). The study will empirically test the relationship between foreign debt and economic growth and whether debt helps promote economic growth or hinder it in the case of Jordan. The choice of the variables used in the study is consistent with economic theory and follow previous studies outlined in the literature section above.

\subsection{Cobb-Douglas Function}

In economics, the Cobb-Douglas production function is a particular functional form of the production function which is widely used to represent the technological relationship between the amounts of two or more inputs, particularly physical capital and labor, and the amount of output that can be produced by those inputs. The 
Cobb-Douglas form was developed and tested against statistical evidence by Charles Cobb and Paul Douglas during 1927-1947.

This study uses the Cobb-Douglas production function to test the relationship between foreign debt and economic growth in Jordan. The production function takes the following form as shown in equation (1):

$$
\text { Ln Yt }=\ln C t+B 1 \operatorname{Ln} K t+B 2 L n L t
$$

Where:

Y: Gross Domestic Product at Market Prices;

K: Gross Fixed Capital Formation;

L: Labor;

Ln: natural logarithm.

\subsection{External Debt and Economic Growth}

The total external debt is added to the Cobb-Douglas production function in order to know the contribution of each variable (Capital, Labor, and External debt) to economic growth. According to equation (2):

$$
L n Y t=L n C t+B 1 L n K t+B 2 L n L t+B 3 L n E X D t
$$

Where:

EXD: Outstanding External Debt (Including Collateralized Bready Bonds);

$\mathrm{Y}, \mathrm{K}, \mathrm{L}:$ as defined earlier in Equation 1.

\subsection{Domestic Debt and Economic Growth}

The total domestic debt is added to the Cobb-Douglas production function in order to know the contribution of each variable (Capital, Labor, and Domestic debt) to economic growth. According to equation (3):

$$
L n Y t=L n C t+B 1 L n K t+B 2 L n L t+B 3 L n G D D t
$$

Where:

GDD: Gross Domestic Debt;

$\mathrm{Y}, \mathrm{K}, \mathrm{L}$ : as defined earlier in Equation 1.

4.4 Long-Term External Debt and Economic Growth

The total long-term external debt is also added to the Cobb-Douglas production function in order to know the contribution of each variable (Capital, Labor, and Long-term external debt) to economic growth. According to equation (4):

$$
L n Y t=L n C t+B 1 L n K t+B 2 L n L t+B 3 L n L T L t
$$

Where:

LTL: Long-Term External Debt;

$\mathrm{Y}, \mathrm{K}, \mathrm{L}$ : as defined earlier in Equation 1.

\section{Empirical Results}

Using the annual data given in Appendix1, I estimated equations 1A through 4A for the period 1990-2013 using the ordinary least squares (OLS) method.

The OLS estimator is consistent when the regressors are exogenous and there is no perfect multicollinearity, and optimal in the class of linear unbiased estimators when the errors are homoscedastic and serially uncorrelated. Under these conditions, the method of OLS provides minimum-variance mean-unbiased estimation when the errors have finite variances. Under the additional assumption that the errors be normally distributed, OLS is the maximum likelihood estimator.

In addition, the results show that the Durbin-Watson (DW) statistic indicates the presence of serial correlation of orders one. The estimated results are reported under the assumption of first-order serial correlation, AR (1).

\subsection{The Estimated Results of Cobb-Douglas Production Function}

The results of estimating equation (1) are given in Appendix (2). As the results show, equation (1) can be written as the following: 


$$
\begin{gathered}
L n Y t=448.7+0.203 \operatorname{LnKt}-0.115 \operatorname{LnLt} \\
(0.011) \quad(2.85) * * * \quad(-1.93) * \\
R^{2}=0.995 \quad F=1267.8 \quad D-W=2.46
\end{gathered}
$$

$* * *, * *$, and * indicate statistical significance at the 1,5 and 10 percent level, respectively, in a two tailed test.

The estimated results of equation (5) show that both Gross Fixed Capital Formation and labor are significant at 1 and 10 percent significance level, respectively, which means that Gross Fixed Capital Formation and labor have significant effect on the gross domestic product. In addition, the estimated results show that the coefficient of Gross Fixed Capital Formation has a positive sign confirming the prediction of the economic theory between Gross Domestic Product and Gross Fixed Capital Formation, while the coefficient of labor has a negative sign which violates the theoretical relationship between gross domestic product and labor. The contribution of Gross Fixed Capital Formation in gross domestic product of 0.203 meaning that the increase in Gross Fixed Capital Formation by 100 percent leads to an increase by 20.3 percent in output. However, the contribution of labor in gross domestic product is- 0.115 , which means that the increase in labor by 100 percent leads to a decrease in output by 11.5 percent.

The calculated value of F-statistics is 1267.8 which is significant at the 1 percent significance level. This means that the estimated model is statistically significant and the independent variables, represented by (Gross Fixed Capital Formation and Labor) have significant effect on the dependent variable (Gross Domestic Product) as given in equation (5). Also, the value of the coefficient of determination $\left(\mathrm{R}^{2}=0.995\right)$ indicates that the independent variables explain $99.5 \%$ of the changes in gross domestic product and the remainder, amounting to $0.05 \%$, are explained by other factors. The value of D-W statistics show the absence of autocorrelation in the model as estimated by equation (5).

\subsection{The Estimated Results of the Impact of External Debt on Economic Growth}

In addition to labor and capital, equation (2) shows the effect of total external debt (EXDt) on GDP as given in Appendix 3. As the results show, equation (6) can be written as the following:

$$
\begin{gathered}
\text { Ln Yt }=548.15+0.176 \text { Ln Kt }-0.118 \text { Ln Lt }-0.092 \text { Ln EXDt } \\
\begin{array}{c}
(0.010) \\
R^{2}=0.995
\end{array} \quad F=960.4 \quad(-35) * * \quad D-W=2.51
\end{gathered}
$$

The results of equation (6) show that the coefficient of external debt is negative. This result may be reasonable, and therefore it shows the negative impact on economic growth as insignificant, which means its relationship with economic growth is weak. However, the effect of each of gross fixed capital formation and labor are statistically significant. The results of this study is consistent with the results of previous studies such as Lyoha (1999), Karagol (2002), Malik et al., (2010), Schclarek, (2004) and Abdulhadi (2013).

The estimated value of the coefficient of determination $\left(\mathrm{R}^{2}=99.5 \%\right)$ means that the explanatory power of regression equation is very strong. That is, the variables of gross fixed capital formation, labor, and external debt explain about 99.5percent of GDP, and the value of D-W statistics show the model has no autocorrelation.

\subsection{The Estimated Results of the Impact of the Domestic Debt on Economic Growth}

Equation (7) shows the impact of the total domestic debt (GDD), in addition to gross fixed capital formation and labor, on gross domestic product. As given in Appendix 4. The estimated results are given in the following equation:

$$
\begin{gathered}
\operatorname{Ln} Y t=6.57+0.156 \mathrm{Ln} \mathrm{Kt}-0.05 \mathrm{Ln} L t+0.328 \mathrm{Ln} G D D t \\
(2.976) * * * \\
R^{2}=0.996 \quad F=1155 \quad D-W=2.52
\end{gathered}
$$

The estimated results given in equation (7) indicate that both gross fixed capital formation and domestic debt are significant and have positive impact on gross domestic product. However, the estimated results show that labor is insignificant and has negative impact on gross domestic product. In addition, the coefficient of determination $\left(\mathrm{R}^{2}=99.6 \%\right)$ shows that $99.6 \%$ of GDP is explained by the variables of the model, and the value of the $\mathrm{D}-\mathrm{W}$ statistics indicates the absence of autocorrelation in the estimated model.

\subsection{The Estimated Results of the Impact of the Long-Term External Debt on Economic Growth}

Equation (8) shows the total effect of long-term external debt, in addition to gross fixed capital formation and labor, on gross domestic product as given in Appendix 5. The estimated results are given in the following 
equation:

$$
\begin{array}{ccc}
\multicolumn{2}{l}{L n Y t=342.63+0.169 \mathrm{Ln} \mathrm{Kt}-0.113 \mathrm{Ln} \mathrm{Lt}-0.140 \mathrm{Ln} \text { LTLt }} \\
(0.017) \quad(2.278) * * * & (-1.944) * * & (-1.388) \\
R^{2}=0.995 & F=999 & D-W=2.58
\end{array}
$$

The estimated results given by equation (8) indicate that gross fixed capital formation is significant and has positive impact on gross domestic product. However, the estimated results show that the long-term external debt is insignificant and has negative impact on gross domestic product, while labor is significant but has negative impact on gross domestic product. In addition, the estimated value of the coefficient of determination $\left(\mathrm{R}^{2}=995\right)$ indicates that the independent variables explain 99.5 percent of the gross domestic product. The estimated value of the D-W statistics shows the absence of autocorrelation in the estimated model.

\section{Concluding Remarks and Recommendation}

This study investigated empirically the effect of debt on economic growth in the case of Jordan during the period 1990-2013. The results show that domestic debt has a positive and significant effect on economic growth. In addition, the results indicate that both external debt and long-term external debt have negative but statistically insignificant impact on economic growth. This leads to say that domestic debt is one of the major determinants of economic growth in Jordan. Therefore, the government needs to consider reform measures such as revenue enhancement or reduction of current expenditures, or increase capital expenditures in order to promote economic growth. It also needs to follow an effective economic reform program which takes into consideration the allowed level of borrowing as laid down in the law of public debt approved by the Council of Ministers.

\section{References}

Abdelhadi, S. (2013). External Debt and Economic Growth: Case of Jordan (1991-2011). Journal of Economics and Sustainable Development, 4(18). Retrieved from http://www.iiste.org/Journals/index.php/JEDS/article/view/8834

Adepoju, A. A., Salau, A. S., \& Obayelu, A. E. (2007). The Effects of External Debt Management on Sustainable Economic Growth and Development: Lessons from Nigeria. Munich Personal RePEc Archive (MPRA) Paper No. 2147. Retrieved from http://mpra.ub.uni-muenchen.de/2147/

Arab Monetary Found. (n.d.). Unified Arab Economic Report. Various issues. Retrieved from http://www.amf.org.ae/content/about-cog-acbma

Butts, H. C. (2009). Short Term External Debt and Economic Growth-Granger Causality: Evidence from Latin America and the Caribbean. The Review of Black Political Economy, 36(2), 93-111. http://dx.doi.org/10.1007/s12114-009-9041-7

Central Bank of Jordan. (n.d.). Annual Statistical Bulletin. Various issues, Amman, Jordan. Retrieved from http://www.cbj.gov.jo/

Chenery, H., \& Carter, N. (1973). Foreign Assistance and Development Performance, 1960-1970. The American Economic Review, LXIII(2). Retrieved from http://wwwwds.worldbank.org/external/default/WDSContentServer/WDSP/IB/2002/11/11/000178830_981 01903372187/Rendered/PDF/multi0page.pdf

Department of Statistics. (n.d.). Statistical Yearbook, various issues, Amman, Jordan. Retrieved from http://www.dos.gov.jo/dos_home_e/main/index.htm

Hameed, A., Ashraf, H., \& Chaudhary, M. (2008). External Debt and its Impact on economic and Business Growth in Pakistan. International Research Journal of Finance and Economics, 20. Retrieved from http://econ3.upm.edu.my/kelasmaya/sumberkursus/t01141/ECN6112/production\%20functin.pdf

International Monetary Fund. (n.d.). World Economic Outlook. Various issues. Retrieved from http://www.imf.org/external/pubs/ft/weo/data/assump.htm

Jayaraman, T. K., \& Evan, L. (2008). Does external debt lead to economic growth in Pacific Island countries. Journal of Policy Modeling, 31, 272-288. http://dx.doi.org/10.1016/j.jpolmod.2008.05.001

Karagol. (2002). The Causality Analysis of External Debt Service and GNP: The case of Turkey. Central Bank Review, 85(5), 1106-1117.

Lyoha, \& Milton. (1999). External debt and economic growth in sub-Saharan African Countries: An econometric study. AERC Research Paper 90 African Economic Research Consortium, Nairobi. Retrieved 
from http://opendocs.ids.ac.uk/opendocs/bitstream/handle/123456789/2227/RP\%2090.pdf?sequence=1

Malik, S., Hayat, K. M., \& Hayat, U. M. (2010). External Debt and Economic Growth: Empirical Evidence from Pakistan. International Research Journal of Finance and Economics, 44, 88-97.

Ministry of Finance. (n.d.). Annual Report. Various issues, Amman, Jordan. Retrieved from http://www.mof.gov.jo/en-us/mainpage.aspx

Ministry of Finance. (n.d.). Jordan, The Public Debt Law for the year 2001. Retrieved from http://www.mof.gov.jo/en-us/mainpage.aspx

Momani, R. (1995). Jordanian Foreign debt: Economic causes and consequences. Journal of King Saud University, Administrative Sciences, (2), VII.

Schclarek, A. (2004). Debt and Economic Growth in Developing and Industrial Countries. Retrieved from https://lup.lub.lu.se/luur/download?func $=$ downloadFile\&recordOId $=1387405 \&$ fileOId $=2061440$

Taybe, H. (2008). The impact of external debt on economic growth in developing countries. Master thesis in Economics, unpublished, University of Algiers.

World Bank. (n.d.). Annual Report. Various issues. Retrieved from http://siteresources.worldbank.org

\section{Appendix A.}

Table A1. Database used in the estimate

\begin{tabular}{|c|c|c|c|c|c|c|}
\hline $\mathrm{t}$ & $\mathrm{Yt}$ & $\mathrm{Kt}$ & $\mathrm{Lt}$ & EXDt & GDDt & LTLt \\
\hline 1990 & 2760.9 & 694.1 & 100849.0 & 4300.0 & 1119.5 & 3327.3 \\
\hline 1991 & 2958.0 & 678.0 & 106097.0 & 4400.0 & 1119.1 & 3752.7 \\
\hline 1992 & 3610.5 & 1049.3 & 111345.0 & 4577.6 & 1119.8 & 4178.1 \\
\hline 1993 & 3884.3 & 1303.6 & 116593.0 & 4229.6 & 1118.3 & 3752.7 \\
\hline 1994 & 4358.3 & 1391.2 & 135215.0 & 4720.5 & 1121.4 & 4004.7 \\
\hline 1995 & 4714.6 & 1395.0 & 149711.0 & 4911.8 & 1115.3 & 4150.0 \\
\hline 1996 & 4912.2 & 1444.8 & 172503.0 & 5164.3 & 1127.5 & 4404.3 \\
\hline 1997 & 5137.4 & 1325.0 & 171552.0 & 4998.1 & 1103.0 & 4276.1 \\
\hline 1998 & 5609.9 & 1187.5 & 175433.0 & 5333.7 & 1152.0 & 4698.8 \\
\hline 1999 & 5778.3 & 1352.7 & 380286.5 & 5510.1 & 1054.0 & 4868.2 \\
\hline 2000 & 5998.7 & 1266.6 & 585140.0 & 5043.5 & 1235.0 & 4669.0 \\
\hline 2001 & 6363.7 & 1235.8 & 575930.0 & 4969.8 & 1397.0 & 4634.9 \\
\hline 2002 & 6794.0 & 1287.3 & 573243.0 & 5350.4 & 1656.0 & 5032.7 \\
\hline 2003 & 7228.7 & 1490.8 & 617466.0 & 5391.8 & 1815.0 & 5310.5 \\
\hline 2004 & 8090.7 & 2005.4 & 705838.0 & 5348.8 & 2082.0 & 5341.9 \\
\hline 2005 & 8925.4 & 2733.7 & 732196.0 & 5056.7 & 2467.0 & 4948.9 \\
\hline 2006 & 11092.6 & 2717.1 & 728079.0 & 5186.5 & 2961.0 & 5080.6 \\
\hline 2007 & 12595.7 & 3334.1 & 725091.0 & 5253.3 & 3695.0 & 5150.4 \\
\hline 2008 & 16108.0 & 4342.9 & 726585.0 & 3640.2 & 5754.0 & 3537.2 \\
\hline 2009 & 16912.2 & 4254.2 & 725838.0 & 3869.0 & 7086.0 & 3766.0 \\
\hline 2010 & 18762.0 & 4298.6 & 726211.5 & 4610.8 & 7980.0 & 3985.6 \\
\hline 2011 & 20476.6 & 4276.4 & 726024.8 & 4486.8 & 9996.0 & 3871.9 \\
\hline 2012 & 21965.5 & 4287.5 & 726118.1 & 4932.4 & 12678.0 & 4327.8 \\
\hline 2013 & 23851.6 & 4281.9 & 726071.4 & 7234.5 & 13440.0 & 4936.2 \\
\hline
\end{tabular}


Appendix B. The Results of Estimating Cobb-Douglas Function

\begin{tabular}{|c|c|c|c|c|}
\hline Dependent Variable: & & & & \\
\hline Method: Least Squar & & & & \\
\hline Date: $06 / 23 / 14$ Time & & & & \\
\hline Sample (adjusted): 1 & & & & \\
\hline Included observation & & & & \\
\hline Convergence achiev & & & & \\
\hline Variable & Coefficient & Std. Error & t-Statistic & Prob. \\
\hline C & 448.6948 & 39970.15 & 0.011226 & 0.9912 \\
\hline LNKT & 0.203275 & 0.071328 & 2.849858 & 0.0102 \\
\hline LNLT & -0.115082 & 0.059595 & -1.931066 & 0.0685 \\
\hline $\mathrm{AR}(1)$ & 0.999801 & 0.018048 & 55.39816 & 0 \\
\hline R-squared & 0.995029 & Mean dependent var & & 8.996027 \\
\hline Adjusted R-squared & 0.994244 & S.D. dependent var & & 0.633468 \\
\hline S.E. of regression & 0.048058 & Akaike info criterion & & -3.076031 \\
\hline Sum squared resid & 0.043883 & Schwarz criterion & & -2.878553 \\
\hline Log likelihood & 39.37435 & Hannan-Quinn criter. & & -3.026366 \\
\hline F-statistic & 1267.795 & Durbin-Watson stat & & 2.456742 \\
\hline Prob(F-statistic) & 0 & & & \\
\hline Inverted AR Roots & 1 & & & \\
\hline
\end{tabular}

\section{Appendix C. The Results of Estimating the Impact of External Debt on Economic Growth}

\begin{tabular}{|c|c|c|c|c|}
\hline Dependent Variable: & & & & \\
\hline Method: Least Squa & & & & \\
\hline Date: $06 / 23 / 14$ Tim & & & & \\
\hline Sample (adjusted): 1 & & & & \\
\hline Included observation & & & & \\
\hline Convergence achiev & & & & \\
\hline Variable & Coefficient & Std. Error & t-Statistic & Prob. \\
\hline C & 548.1465 & 55637.38 & 0.009852 & 0.9922 \\
\hline LNKT & 0.176322 & 0.074887 & 2.354513 & 0.0301 \\
\hline LNLT & -0.118546 & 0.059269 & -2.000126 & 0.0608 \\
\hline LNEXDT & -0.091821 & 0.085303 & -1.076403 & 0.296 \\
\hline $\operatorname{AR}(1)$ & 0.999829 & 0.017633 & 56.70356 & 0 \\
\hline R-squared & 0.995336 & Mean dependent var & & 8.996027 \\
\hline Adjusted R-squared & 0.9943 & S.D. dependent var & & 0.633468 \\
\hline S.E. of regression & 0.047827 & Akaike info criterion & & -3.052808 \\
\hline Sum squared resid & 0.041173 & Schwarz criterion & & -2.805961 \\
\hline Log likelihood & 40.10729 & Hannan-Quinn criter. & & -2.990727 \\
\hline F-statistic & 960.3783 & Durbin-Watson stat & & 2.510105 \\
\hline Prob(F-statistic) & 0 & & & \\
\hline Inverted AR Roots & 1 & 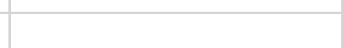 & & \\
\hline
\end{tabular}


Appendix D. The Results of Estimating the Impact of the Domestic Debt on Economic Growth

\begin{tabular}{|c|c|c|c|c|}
\hline \multicolumn{5}{|c|}{ Dependent Variable: LNYT } \\
\hline \multicolumn{5}{|c|}{ Method: Least Squares } \\
\hline \multicolumn{5}{|c|}{ Date: 06/23/14 Time: $14: 15$} \\
\hline \multicolumn{5}{|c|}{ Sample (adjusted): 19912013} \\
\hline \multicolumn{5}{|c|}{ Included observations: 23 after adjustments } \\
\hline \multicolumn{5}{|c|}{ Convergence achieved after 12 iterations } \\
\hline Variable & Coefficient & Std. Error & t-Statistic & Prob. \\
\hline C & 6.574527 & 2.208896 & 2.976386 & 0.0081 \\
\hline LNKT & 0.155784 & 0.072565 & 2.146827 & 0.0457 \\
\hline LNLT & -0.05071 & 0.06528 & -0.776805 & 0.4474 \\
\hline LNGDDT & 0.328523 & 0.129667 & 2.533582 & 0.0208 \\
\hline $\mathrm{AR}(1)$ & 0.929266 & 0.059394 & 15.64571 & 0 \\
\hline R-squared & 0.99612 & Mean dependent var & & 8.996027 \\
\hline Adjusted R-squared & 0.995257 & S.D. dependent var & & 0.633468 \\
\hline S.E. of regression & 0.043625 & Akaike info criterion & & -3.236697 \\
\hline Sum squared resid & 0.034257 & Schwarz criterion & & -2.98985 \\
\hline Log likelihood & 42.22201 & Hannan-Quinn criter. & & -3.174615 \\
\hline F-statistic & 1155.17 & Durbin-Watson stat & & 2.523143 \\
\hline Prob(F-statistic) & 0 & & & \\
\hline Inverted AR Roots & 0.93 & & & \\
\hline
\end{tabular}

Appendix E. The Results of Estimating the Impact of the Long-Term External Debt on Economic Growth

\begin{tabular}{|c|c|c|c|c|}
\hline Dependent Variable: & & & & \\
\hline Method: Least Squar & & & & \\
\hline Date: $06 / 23 / 14$ Time & & & & \\
\hline Sample (adjusted): 1 & & & & \\
\hline Included observation & & & & \\
\hline Convergence achiev & & & & \\
\hline Variable & Coefficient & Std. Error & t-Statistic & Prob. \\
\hline C & 342.6296 & 20180.43 & 0.016978 & 0.9866 \\
\hline LNKT & 0.168967 & 0.074166 & 2.278236 & 0.0351 \\
\hline LNLT & -0.11285 & 0.058057 & -1.943776 & 0.0677 \\
\hline LNLTLT & -0.140353 & 0.101121 & -1.387966 & 0.1821 \\
\hline $\operatorname{AR}(1)$ & 0.999722 & 0.017173 & 58.21407 & 0 \\
\hline R-squared & 0.99552 & Mean dependent var & & 8.996027 \\
\hline Adjusted R-squared & 0.994524 & S.D. dependent var & & 0.633468 \\
\hline S.E. of regression & 0.046875 & Akaike info criterion & & -3.092997 \\
\hline Sum squared resid & 0.039551 & Schwarz criterion & & -2.84615 \\
\hline Log likelihood & 40.56947 & Hannan-Quinn criter. & & -3.030916 \\
\hline F-statistic & 999.9457 & Durbin-Watson stat & & 2.583173 \\
\hline Prob(F-statistic) & 0 & & & \\
\hline Inverted AR Roots & 1 & & & \\
\hline
\end{tabular}

\section{Copyrights}

Copyright for this article is retained by the author(s), with first publication rights granted to the journal.

This is an open-access article distributed under the terms and conditions of the Creative Commons Attribution license (http://creativecommons.org/licenses/by/3.0/). 